\title{
凸型マイクロバンプの形状制御
}

\author{
近藤 和夫 ${ }^{*}$, 田中 善之助 ${ }^{*}$, 江口 宗博*
}

\section{Shapes Evolution of Electrodeposited Center Humped Bump}

Kazuo KONDO*, Zennosuke TANAKA* and Munehiro EGUCHI*

* 周山大学工学部物質応用化学科（７00-0082 岡山県周山市津島中3-1-1）

*Department of Applied Chemistry, Faculty of Engineering, University of Okayama (3-1-1 Tsushima-Naka, Okayama-shi, Okayama 700-0082)

\begin{abstract}
Center humped bump is ideal shape for high density interconnection. This is because of smaller interconnection area and less lateral expansion in thermal compression. Coumarin additive was found to show inhibition effect and diffusion control from current-potential curves with rotation disk electrode. The two layered photo resist structure was newly introduced. With two layered resist structure and Coumarin, we succeeded in forming center humped bumps. The center humped bump has aspect ratio of 0.6 having $12 \mu \mathrm{m}$ height and $20 \mu$ m diameter.
\end{abstract}

Key Words: Bumps, Center Humped, Coumarin, Two Layered Resist, Electrodeposition

\section{1. 緒 言}

最近の電子機器の小型軽量化, 高性能化に伴い, 配線, 接続，パッケージングなどの実装分野の著しい技術革新が 求められている。特にマイクロプロセッサ等の多ピンの半 導体素子では, そのピンピッチが著しく高密度化し, バー ンイン試験と接続方法とが非常に重要となる ${ }^{1,2)}$ 。

バンプは高密度接続が可能な突起状のマイクロコネクタ である。異方性導電膜等によるフリップチップ用接合突起, 液晶用等の検查プローブ用突起にはニッケルめっきで形成 した高硬度の凸型形状のマイクロコネクタを必要とする。 バンプとパッドとを接続するとき，加圧により接続するた めバンプは横方向への広がりを生じる。今後はバンプ間ピ ッチ（隣接バンプとの中心間距離）が30 $\mathrm{mm}$ 以下となり, 接続がさらに狭ピッチ化する。そのため, 高密度で接続時 の横方向への広がりを抑えることが可能な中央の盛り上が った凸型形状のバンプの開発が必要となっている。

バンプの形状制御に関する系統的な研究は，近藤 314 らに よってなされている。近藤らは，金バンプに関してのフォ トレジストのカソード径, 電解夜流れ, 添加剤の影響につ いて検討し, 拡散律速下での初期バンプ形成機構に関して 考察した。宇野, 近藤ららはカソード径, レイノルズ数, 添加剤についてのバンプ形状を観察した。横山, 近藤らら は 2 次電流密度分布および拡散律速での電流密度分布につ いてバンプ形状を観察し, 数值解析との一致を検討した。 福井, 近藤”らは, レジスト側壁角度による物質移動を数 值流体解析し, はく離渦, 外部拡散と電流密度分布との関
係を求めた。門田, 近藤豆らは, 添加郕, 電流密度および カソード径のバンプ形状への影響について検討し，1次電 流密度分布および 2 次電流密度分布における凹型バンプ形 成機構について考察した。江口, 近藤りらは, 凹型形状バ ンプが異方性導電膜を用いた接続に対して与える影響につ いて，捕獲粒子数の測定などから検討し考察した。

本研究ではNiバンプの形状制御を行うために添加剂と してクマリンを使用した。クマリンは金属表面の研磨傷を Niめっきで平坦化するときに従来経験的に用いられてき た添加版である。クマリンに関する研究はKluglikov, Dukovic，Landoltらによってなされている。Kluglikov ${ }^{10}$ らは, 回転円板電極を用いた分極測定からクマリンはNi 析出抑制効果がある拡散律速性になりやすい添加剤である

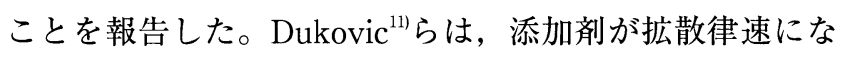
つた場合の挙動について移動境界法による数値解析を行 い，ストレートウォール型バンプの成長シミュレーション を行った。その結果, 添加剤のNi析出抑制作用とレジス 卜側壁角度により凹または凸型 $\mathrm{Ni}$ バンプができると報告

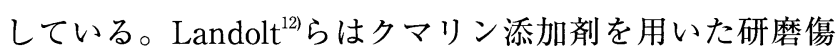
の平坦化について，数值解析と実験結果との比較から検討 している。Kardos ${ }^{13)}$ らは分極測定と溝へのめっきを行い, 添加剤の働きについて検討した。Thomas ${ }^{14}{ }^{14}$ は濃度勾配, 拡散層, 添加剤と金属イオンの拡散速度の違いなどを検討 し, 平坦化のメカニズムについて説明した。また, 逢坂 ${ }^{15}$ らはプロパギルアルコールを使用して, 高アスペクト比の 電析Niマイクロプローブの作製を検討している。

本研究では，微細化接続，バーンイン試験に対応するた 
め, 中央が盛り上がった凸型形状Niバンプの作製を検討 した。添加剤としてクマリンを用い，レジスト側壁角度や レジスト構造を変化させることにより, 凸型 $\mathrm{Niバンプの}$ 作製を検討した。また, 分極測定やレジスト構造を変化さ せたバンプ作製実験から, 形状制御機構についても検討し た。

\section{2. 実験および測定方法}

電解液は, 硫酸ニッケル七水和物 (和光純薬) $300 \mathrm{~g} / \mathrm{L}$ と塩化ナトリウム（和光純薬） $15 \mathrm{~g} / \mathrm{L}$ とウ酸 $30 \mathrm{~g} / \mathrm{L}$ とイ オン交換水とにより調製した。これに添加剤としてクマリ ン (和光純薬) を $0,0.2 \mathrm{~g} / \mathrm{L}$ 添加して電解液とした (Table 1 )。フォトレジストには， 1 層の場合にはPLA900 (東京応化製) を， 2 層の場合にはPLA-900と THB $430 \mathrm{~N}$ (JSR）とを組み合わせたものを使用した。銅䇴上に リソグラフパターンを形成し，その銅箔を回転円板電極に 設置した。バンプは銅箔上のパターンに定電流電解により 作製した。電極回転速度100r.p.m., 電流密度 $10 \mathrm{~mA} / \mathrm{cm}^{2}$ と し， $60 \mathrm{C} / \mathrm{cm}^{2}$ 析出させた。作製したバンプは, SEMにより $1.05 \mathrm{rad}$ 試料ステージを傾斜させ観察した。

電流電位曲線をカソード分極により測定した。参照電極 には3.33MKCl-AgClを用いた。めっき浴と添加剤はバンプ 作製に用いたものを使用した。定電流電解を行い 5 分後の 電位を読み取った。

\section{3. 結果と考察}

\section{1 分極測定結果}

Fig. 1 は添加剤クマリンの添加量と回転円板電極の回転

Table 1. Electroplating bath composition

\begin{tabular}{c|c}
\hline $\mathrm{NiSO}_{4} \cdot 7 \mathrm{H}_{2} \mathrm{O}$ & $300 \mathrm{~g} / \mathrm{L}$ \\
\hline $\mathrm{NaCl}$ & $15 \mathrm{~g} / \mathrm{L}$ \\
\hline $\mathrm{H}_{3} \mathrm{BO}_{3}$ & $30 \mathrm{~g} / \mathrm{L}$ \\
\hline $\mathrm{pH}$ & 5.5 \\
\hline Coumarin & $0,0.2 \mathrm{~g} / \mathrm{L}$ \\
\hline
\end{tabular}

数とを変化させて行った分極測定結果である。横軸が電極 電位であり, 縦軸が電流密度である。添加剤濃度は 0 およ び $0.2 \mathrm{~g} / \mathrm{L} と し$, 回転円板電極の回転数は $0,10,50$, 100r.p.m.と変化させた。クマリンを添加することで分極が 大きくなり, 曲線は右にシフトした。このことから添加剤 クマリンにNi析出抑制効果があることがわかる。また,

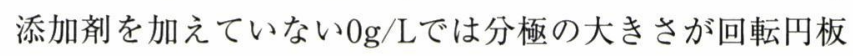
電極の回転数に依存しなかったが, 添加剤を加えた $0.2 \mathrm{~g} / \mathrm{L}$ では, 分極が回転円板電極の回転数に依存し回転数の増加 により大きくなった。このことから,この実験条件では添 加剂クマリンは拡散律速性になっていると推定される。

\section{2 レジスト側壁角度を変化させたバンプの作製}

Fig. 2 は，レジスト側壁角度を変化させて作製したスト レートウォール型バンプのSEM断面観察結果である。作 製条件はレジスト膜厚 $20 \mu \mathrm{m}$, カソード径 $100 \mu \mathrm{m}$, 電流密 度 $10 \mathrm{~mA} / \mathrm{cm}^{2}$, 電気量は $60 \mathrm{C} / \mathrm{cm}^{2}$, 添加剤濃度は $0.2 \mathrm{~g} / \mathrm{L} て ゙$ ある。aはレジスト側壁角度が垂直の場合, bはレジスト 側壁角度が正の開口パターンの場合である。レジスト側壁 角度が垂直(a)の場合では添加剂を加えても平坦な形状で あった。レジスト側壁角度が正（b, 開口形状）の場合で は, バンプ形状は丸みを持った。Dukovic ${ }^{11 !} ら$ は, 析出抑 制効果を持つ拡散律速性の添加剤（クマリン等）をバンプ 作製に使用すると, 中央が顕著に盛り上がった凸型形状の ストレートウォールバンプが形成されることを数值解析シ ミュレーションにより予想している。しかしながらわれわ れの実験では, バンプ中央は盛り上がらなかった。そこで, この厚膜レジストに薄膜レジストを設置し, レジスト構造 を 2 層にすることで凸型形状のバンプの作製を検討した。

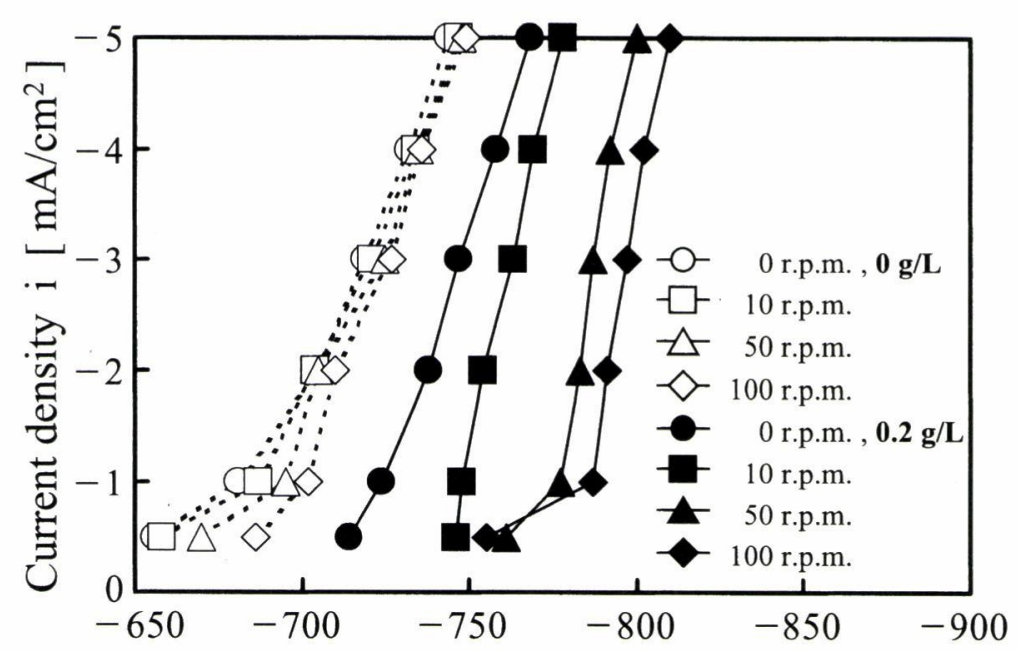

Electrode potential E vs. 3.33M KCl-AgCl [ $\mathrm{mV}$ ]

Fig.1 Current-potential curves for different rotation speeds of R.D.E. 


\section{32 層レジスト}

レジスト側壁角度を変化させる実験の中で, カソード端 部にレジスト残渣が残ると凸型形状バンプが作製されるこ とを発見した。そこで，この残渣の影響を積極的に活かす ためにレジストを 2 層にすることを検討した。Fig. 3 は 2 層レジストパターンの模式図である。以後, 上の厚膜レジ ストを上層レジスト, 下の薄膜レジストを下層レジストと 呼ぶ。

\subsection{1 下層レジスト径の影響}

Fig. 4 は， 2 層レジストパターンに作製したバンプの SEM観察結果である。使用した 2 層レジストパターンは 上層径 $100 \mu \mathrm{m}$, 上層膜厚 $20 \mu \mathrm{m}$ であり, それに下層レジス トとして膜厚 $1 \mu \mathrm{m}$ のレジストを設置した。下層径は 60,40 , $20 \mu \mathrm{m}$ と変化させた。aは下層径 $60 \mu \mathrm{m}, \mathrm{b}$ b下層径 $40 \mu \mathrm{m}, \mathrm{c}$ は下層径 $20 \mu \mathrm{m}$ である。作製条件は電流密度 $10 \mathrm{~mA} / \mathrm{cm}^{2}$, 電気量 $60 \mathrm{C} / \mathrm{cm}^{2}$, 添加郕濃度 $0.2 \mathrm{~g} / \mathrm{L}$ である。aの下層径

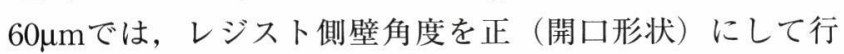
った実験結果（Fig.2-a）よりも著しく中央の盛り上がりが 大きくなった。cでも中央の盛り上がった凸型バンプを作 製することができた。なお，dのクマリン無添加の場合に は, 本 2 層レジストパターンを用いても著しい中央の盛り 上がりは観察されなかった。さらに盛り上がりを大きくす るために上層径を小さくした。

\subsection{2 上層レジス卜径の影響}

Fig. 5 は，上層径を $100 \mu \mathrm{m}$ から $40 \mu \mathrm{m}$ 一とさくして作 製したバンプのSEM観察結果である。Fig. 6 はその断面観 察結果である。作製条件は上層膜厚 $20 \mu \mathrm{m}$, 上層径 $40 \mu \mathrm{m}$, 下層膜厚 $1 \mu \mathrm{m}$, 下層径 $20 \mu \mathrm{m}$, 電流密度 $10 \mathrm{~mA} / \mathrm{cm}^{2}$, 電気 量 $60 \mathrm{C} / \mathrm{cm}^{2}$, 添加郕濃度 $0.2 \mathrm{~g} / \mathrm{L}$ である。

上層径を小さくすることでさらに中央の盛り上がった形 状のバンプを作製することができた。作製されたバンプは,

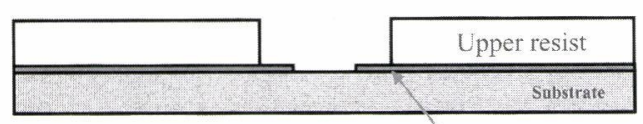

Lower resist

Fig.3 Schematic illustration of two layers resist structure

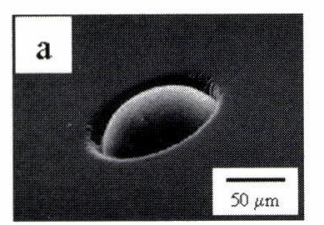

a) $60 \mu \mathrm{m}$ in lower resist diameter

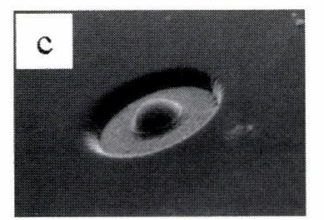

c) $20 \mu \mathrm{m}$

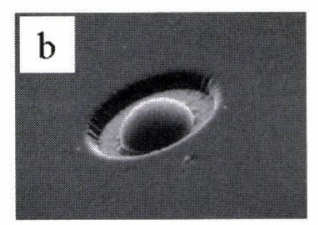

b) $40 \mu \mathrm{m}$

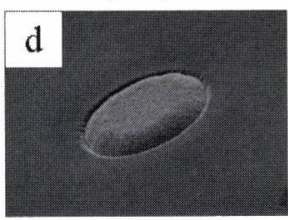

d) Without Coumarin $(60 \mu \mathrm{m}$ in lower resist diameter)
Fig.4 Bumps electrodeposited onto different lower resist diameters with two layers resist structure. Upper resist diameter is $100 \mu \mathrm{m}$
バンプ径が約 $20 \mu \mathrm{m}$ でバンプ高さが約 $12 \mu \mathrm{m}$ であり，アスペ クト比が約0.6であった（Fig. 6$)$ 。

\section{4 形状制御機構}

Fig. 7 はクマリンの外部拡散の様子を表した模式図であ る。カソード上でNiが析出するとクマリンもカソード上 で消費される。一方レジスト上面ではクマリンは消費され ない。またクマリンは拡散律速になっていると考えられる (Fig. 1)。そのため高クマリン濃度のレジスト上面から低 濃度のカソード上にクマリンが拡散する。クマリンの拡散 を伴うカソード端部では中央部分に比ベクマリンの供給が 多くなる。これを外部周辺拡散と言う。この外部周辺拡散 の影響によりカソード端部ではめっき成長が強く抑制され る。しかしながら中央部では抑制されず，凸型形状バンプ が形成されたと考えられる。

\section{4. 結 言}

バンプは高密度接続が可能な突起状のマイクロコネクタ である。今後さらに高密度化していく半導体素子の接続で は，接続時に横方向への変形の少ない中央が盛り上がった 形状のバンプが求められている。本研究では, 拡散律速性 になりやすく， Ni析出抑制効果のある添加剤クマリンを 用い，レジストの構造を変化させることにより，凸型形状 Niバンプの作製を検討した。結論を以下に示す。

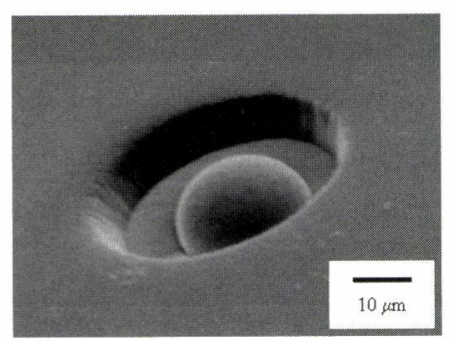

Fig.5 Bump electrodeposited onto smaller upper resist diameter with two layers resist structure. Upper resist diameter is $40 \mu \mathrm{m}$ and lower resist diameter is $20 \mu \mathrm{m}$

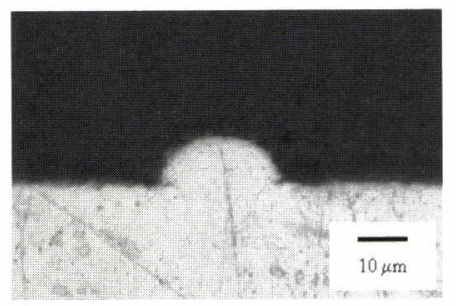

Fig.6 Bump electrodeposited onto smaller upper resist diameter with two layers resist structure. Upper resist diameter is $40 \mu \mathrm{m}$ and lower resist diameter is $20 \mu \mathrm{m}$

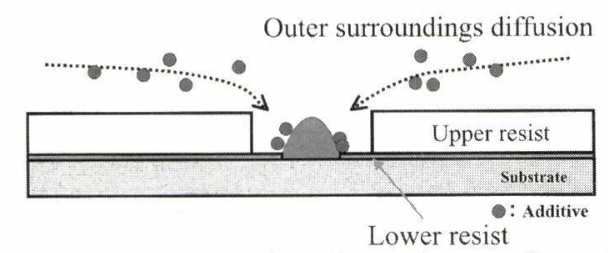

Fig.7 Schematic illustration of outer surroundings diffusion of additive 
1) 分極測定より, 添加剤濃度が増加すると分極が大き くなった。添加剤にはNi析出抑制効果がある。また, 添加剂を加えると電極回転速度の増加に伴い分極が大 きくなった。添加剂クマリンはNi析出抑制効果を有 し,この条件では拡散律速性になっていると推定され る。

2) 2 層レジストを用いて凸型形状バンプの作製を検討 した。下層径 $60 \mu \mathrm{m}$ 40, $20 \mu \mathrm{m}$ とさくするにつれて 中央の盛り上がりが大きくなった。また上層径を $40 \mu \mathrm{m}$ 小さくしてバンプ作製を行った。バンプ径は 約 $20 \mu \mathrm{m}$ でバンプ高さが約 $12 \mu \mathrm{m}$ であり, アスペクト比 が0.6であった。

(2001.5.10-受理)

\section{記号表}

$\mathrm{i}:$ 電流密度 $\left[\mathrm{mA} / \mathrm{cm}^{2}\right]$

$\mathrm{E}:$ 電極電位 $[\mathrm{mV}]$

\section{文献}

1) R.R.Tummala and E.J.Rymaszewski: "Microelectronics Packaging Handbook", Van Norstrand Reinholt, pp.30-42, 1988

2）畑田賢造：“TAB技術入門”，工業調査会，p.73，1990

3) K.Kondo, T.Miyazaki and Y.Tamura: "Shape Formation of Electrodeposited Gold Bumps", Journal of Electrochem. Soc., Vol.141, p.1644, 1994

4) K.Kondo, T.Miyazaki and Y.Tamura : "Shape Formation of Electrodeposited Gold Bumps", Proceeding of 183rd Meeting of Electrochemical Society, Honolulu, May, p.58, 1993

5) K.Kondo, K.Fukui, K.Uno and K.Shinohara: "Shape Evolution of Electrodeposited Copper Bumps", Journal of
Electochem. Soc.,Vol.143, p.1880, 1996

6) K.Kondo, K.Fukui, M.Yokoyama and K.Shinohara : “Shape Evolution of Electrodeposited Copper Bumps with High Peclet Numbers”, Journal of Electrochem. Soc., Vol.144, p.466, 1997

7) K.Kondo and K.Fukui : "Current Evolution of Electrodeposited Copper Bumps with Photoresist Angle", Journal of Electrochem.Soc., Vol.145, p.840, 1998

8) K.Kondo, Z.Tanaka and T.Monden : "Shape Evolution of Electrodeposited Bumps with Additive”, Electrochemica Acta, Vol.1, p.2530, 1999

9) 近藤和夫, 田中善之助, 江口宗博, 門田卓也 : “添加剤によ るめっきバンプの形状制御とCOG接続特性”, エレクトロ ニクス実装学会誌, Vol.3, p.303, 2000

10) S.S.Kruglikov, N.T.Kudriavtsev, G.F.Vorobiova and A.Y. Antonov: "On the Mechanism of Leveling by Addition Agents in Electrodeposition of Metal", Electrochemica Acta., Vol.10, pp.253-261, 1965

11) J.O.Dukovic : "Feature-Scale Simulation of Resist-Patterned Electrodeposition", Journal of IBM Research and Development, Vol.37, pp.125-141, 1993

12) C.Madore and D.Landolt : "Blocking Inhibitors in Cathodic Leveling”, Journal of Electrochem. Soc., Vol.143, p.3936, 1996

13) O.Kardos : "Current Distribution on Microprofiles Part I", Plating February, p.129, 1974

14) J.D.Thomas : "Leveling, Definition, Measurement and Understanding”, Proc. Amer. Electropl. Soc. Vol.43, p.60, 1956

15) 逢坂哲彌 : “高アスペクト比を有する電析 Niマイクロプロー ブの試作”，表面技術，Vol.52，No.1，p.130，2001 